\title{
Influence of Strategic Innovation Management on Competitiveness of Technical Vocational Education and Training (TVET) Institutions in Kenya
}

Monica Njeri Gachunga, Patrick Ngugi Karanja, Allan Njogu Kihara

To Link this Article: http://dx.doi.org/10.6007/IJARBSS/v10-i11/8256

DOI:10.6007/IJARBSS/v10-i11/8256

Received: 10 October 2020, Revised: 23 October 2020, Accepted: 19 November 2020

Published Online: 30 November 2020

In-Text Citation: (Gachunga et al., 2020)

To Cite this Article: Gachunga, M. N., Karanja, P. N., \& Kihara, A. N. (2020). Influence of Strategic Innovation Management on Competitiveness of Technical Vocational Education and Training (Tvet) Institutions in Kenya. International Journal Academic Research in Business and Social Sciences, 10(11), 1334-1346.

\section{Copyright: (c) 2020 The Author(s)}

Published by Human Resource Management Academic Research Society (www.hrmars.com)

This article is published under the Creative Commons Attribution (CC BY 4.0) license. Anyone may reproduce, distribute, translate and create derivative works of this article (for both commercial and non-commercial purposes), subject to full attribution to the original publication and authors. The full terms of this license may be seen at: http://creativecommons.org/licences/by/4.0/legalcode

Vol. 10, No. 11, 2020, Pg. 1334 - 1346

Full Terms \& Conditions of access and use can be found at http://hrmars.com/index.php/pages/detail/publication-ethics 


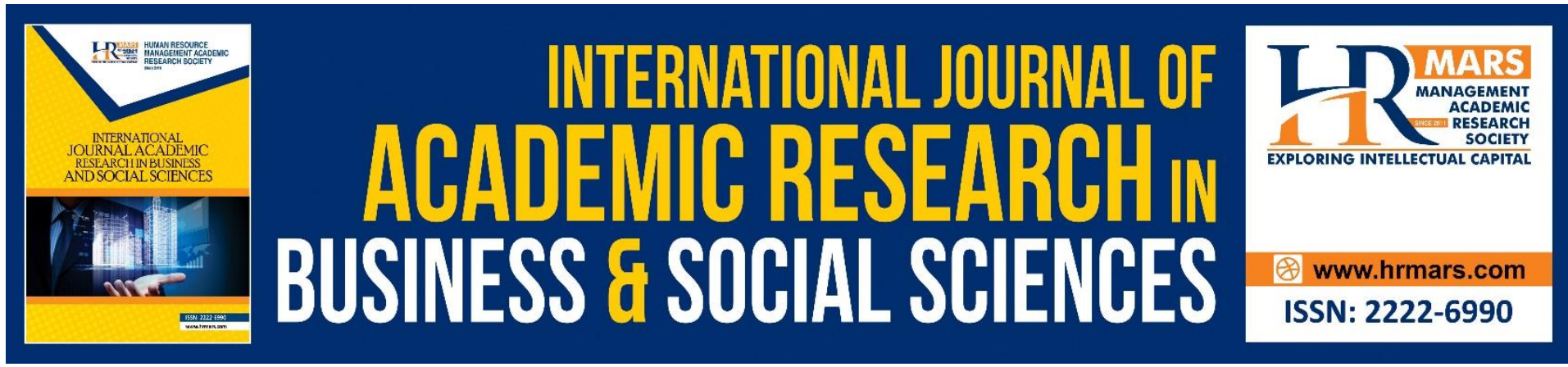

\title{
Influence of Strategic Innovation Management on Competitiveness of Technical Vocational Education and Training (TVET) Institutions in Kenya
}

\author{
Monica Njeri Gachunga \\ PhD Candidate, Jomo Kenyatta University of Agricultue and Technology (JKUAT) \\ Email: mgachunga2012@gmail.com
Dr. Patrick Ngugi Karanja, Dr. Allan Njogu Kihara JKUAT \\ Email:ngugipk1@gmail.com,njoguak@gmail.com
}

\begin{abstract}
The aim of this paper is to assess the influence of strategic innovation management on the competitiveness of TVET institutions in Kenya. Strategic innovation management has been highly regarded to be essential in leading businesses to success through commitment, effective decision making as well as mobilizing resource required for business operations. TVET institutions on the other hand have been recognized as key economic drivers in both developing and developed countries across the globe. The institutions have highly contributed to growth of industries especially the manufacturing sector through provision of the required skills. In Kenya, TVET institutions are yet to gain the required attention based on the fact that they are regarded as the last running point for academic failures. This perception has made the competitiveness of these institutions a nightmare especially with the growing number of universities and other higher learning institutions with more financial muscle and competencies than the TVET institutions. Descriptive research design was used in the study and the target population were the 68 TVET institutions in Kenya. A census was employed whereby all the 68 institutions were included in the study. Principals/their representatives/ HoD ICT, R\&D and Finance were the units of observation. The study employed structured questionnaires to obtain the data which was analysed by mixed method analysis. The findings revealed that strategic innovation significantly influenced the competitiveness of TVET institutions in Kenya. The study concluded that while most of the TVET institutions recognised the need for strategic innovation, it was not upheld in the operations of the institutions. The study therefore recommended that the management of the TVET Institutions in Kenya ought to uphold innovativeness as way of creating a more dynamic and results-oriented working environment.
\end{abstract}

Keywords: Strategic Leadership, Strategic Innovation Management, Organizational Competitiveness, TVET institutions 


\section{Introduction}

\section{Background of the Study}

Armstrong (2013) defines leadership is the ability of an individual to influence followership through example setting and involving the followers by showing them the way. It is the ability of a manager to embrace and appreciate the role and existence of employees and other stakeholders in an organization through which synergy in growth and development is achieved. One of the major aspects of strategic leaders is being innovative. According to Norzailan et al. (2016), strategic leadership is about thinking, planning and acting uniquely and seeking to take better paths aimed towards gaining success. Arham (2014) comes in support of this to illuminate that leadership can be a normal procedure of influencing followership which can be practiced by even the least performing organizations but when it comes to strategic leadership, it is about choosing a unique stand and doing what means the best for the firm. Pazireh, Akhlagh and Akbari (2014) considered strategic leadership as a way of management where the management of an organization puts the appropriate measures in ensuring the organizational resources are effectively used by bringing in new changes such as technology and innovation thus steering performance and competitiveness.

The organizational innovation is the introduction of new organizational business management methods in the workplace and/or the relationship between a company and external agents (Paul, 2012). According to Owolabi and Makinde (2015), the organizational innovations are strongly linked with all administrative efforts to renew organizational routines, procedures, mechanisms, systems, among others in order to renew teamwork, sharing of information, coordination, collaboration, learning and innovation.

The organizational innovation is considered a source of sustainable competitive advantage (Sayem, 2012). Also, the organizational innovations are strongly associated with all administrative efforts to renew organizational routines, procedures, mechanisms, systems, etc. and in order to promote teamwork, sharing of information, coordination, collaboration, learning and innovation (Owolabi, \& Makinde, 2015).

As regarded by a growing body of researchers innovation is a catalyst of performance in business and economy. Mutindi, Namusonge and Obwogi (2013) refer to innovation as 'the introduction of a new thing or method. Innovativeness refers to 'a firm's capacity to engage in new enterprise that is, introduction of new processes, products, or ideas in the organization'. This capacity to innovate is among the most important factors which influence the business performance and as such, innovativeness is amongst the unique culture which embeds in the tangible and intangible resources leading a firm towards successful business performance (Paul, 2012).

TVET education has been used in many countries across the World to equip youth with skills and knowledge to address the problem of youth unemployment (lacovou and Arnstein, 2007). Countries like Taiwan, China and India went further to use TVET as a means for supporting creation of skilled work force (UNESCO, 2009). This increases productivity and hence economic growth. But the role of TVET goes further to promotion of social development. This shows that TVET has varying roles on development. In Kenya, a quality and relevant TVET system has been emphasized for national economic growth and global competitiveness as well as holding a strategic position in effective implementation of Kenya Vision 2030 and the Big Four Agenda (KIPPRA, 2019).

On the other hand, developing a sustainable competitive advantage in the competitive market setting is the main challenge that most firms face. According to Dyllick and Muff (2016), competitive advantage is the leverage that a business has over its competitors. 
Anderson (2014) posits that competitiveness tries to address a portion of the reactions of near favourable position. In the context of TVET institutions, competitiveness stands for the ability of these organizations to offer better services and more preferred than their peers in the same market and with the same operational capacity. With many universities and other higher learning institutions across the country, TVET institutions stand to face steeper competition thus they ought to be more strategic so as to gain competitive advantage (Agnihotri \& Rapp, 2011) For the purpose of the study, organizational competitiveness will be addressed by the completion rate, staff turnover, number of accredited programs as well as students' population.

\section{Statement of the Problem}

The quality and relevant TVET system is critical for effective realization of the Kenya Vision 2030 and big-four agenda based on human capital development, competiveness and enterprise creation. This therefore makes their competitiveness and continued existence a subject of concern. Over the past ten years, there have been deliberate efforts by the Kenyan Government through legislative framework reforms and increased public spending on TVETs across the country. However, despite the efforts by the government to enhance competitiveness of the TVET institutions, their competitiveness still remains minimal as evidenced by continued decrease in students' enrolment, low transition rates and increased staff turnover (TVETA, 2018; RoK, 2018). Previous evidence shows that strategic innovation management is a key driver to the competitiveness of educational institutions. This however, is yet to be proved in the context of TVET institutions in Kenya hence this study sought to fill the gaps by assessing the influence of strategic innovation management on the competitiveness of TVET institutions in Kenya.

\section{Objectives}

$>$ To establish the influence of strategic innovation management on the competiveness of TVET institutions in Kenya.

\section{Literature Review \\ Theoretical Review \\ Diffusion Theory of Innovation}

Diffusion theory of innovation was first introduced by Rogers (2003). The theory seeks to explain how, why, and at what rate new ideas and technology spread. The scholar aimed at identifying the ways in which organizations can use to enhance innovation and thus increase their sustainability. As cited by Perla, Tonetti, and Waugh (2015), Rogers termed innovation as the degree to which organizations come up with new ideas and implement them in order to acquire returns. The way toward receiving new developments has been considered for more than 30 years, and a standout amongst the most well-known selection models is portrayed by Rogers in his book, Diffusion of Innovations (Syverson, 2011). Much research from a wide assortment of controls has utilized the model as a system. Rogers (2003) referenced a few of these orders as political theory, general wellbeing, correspondences, history, financial matters, innovation, and training, and characterized Rogers' hypothesis as a broadly utilized hypothetical system in the territory of innovation dispersion and reception (Amurle, 2013; Jagdeep and Singh, 2013).

Rogers' dissemination of advancements hypothesis is the most proper for examining the selection of innovation in associations (Kemmerer and Lu, 2012; Lashkari, 2016; Comin, and 
Hobijn, 2010). The dissemination examine includes mechanical advancements. Rogers (2003) generally utilized innovation and development as equivalent words. He stated that innovation is a structure for instrumental activity that lessens the vulnerability in the reason impact connections engaged with accomplishing an ideal result. It is made out of two sections: equipment and programming. Equipment is the instrument that exemplifies the innovation as a material or physical item while programming is the database for the device (Alese and Alimi, 2014; Elbanna, 2010).

Since programming (as a mechanical development) has a low dimension of being recognized, its rate of appropriation is very moderate. For Rogers (2003), appropriation is a choice of full utilization of development as the best strategy accessible and dismissal is a choice not to receive advancement. Rogers characterizes dispersion as the procedure in which advancement is imparted exhaustive certain channels after some time among the individuals from a social framework. According to Tesot (2012), innovativeness determines the level of commitment to success that the organization is delivering. Hence, the leaders need to encourage employees to shift their attitude from being mere workers to real innovators and the institutions are more likely to be competitive and sustainable.

Rogers (2003) came up with innovation diffusion process which he defined as an activity meant to seek and process information regarding innovation decision making. As cited by Sampson (2015), Rogers (2003) provides five steps for innovation decision making process. The steps include knowledge, persuasion, decision, implementation and confirmation. TVET institutions need to first seek knowledge on the strategies that they can use to expand from sources such as employees, competitors, consultants and other online platforms. According to Perla and Tonetti (2014) and Fwaya, Odhuno, Kambona and Othuon (2012), posited that knowledge is the basis for identifying best ideas for the purpose of implementing and realization of a competitive organization. Persuasion is the stage whereby individuals expresses either negative or positive attitude towards the innovation ideas put across by the organizational management.

TVET institutions leaders need to persuade the trainers or employees to accept the new innovation ideas at this stage (Buera \& Oberfield, 2015). Rogers (2003) states that despite the knowledge stage being more cognitive, the persuasion stage is more effective for managers to impose the changes on the minds of employees. Decision stage is another important stage. It plays a vital role in determining whether one is ready to adopt the innovation ideas or not. Peres, Muller and Mahajan suggested that diffusion is the process of the organization performance and penetration of new products to the market. This is driven by social influences, which include all interdependencies among consumers that affect various market players with or without their explicit knowledge (Hayden, 2009; Byles, Aupperle \& Arogyaswamy, 2011).

Managers/principals of the TVET institutions should instil innovation in the employees and ensure that they adopt and adapt to the innovation culture by ensuring that they are aware of the merits of accepting the same (Roberts, Galluch, Dinger \& Grover, 2012). After innovation culture is instilled in the employees, implementation should follow whereby the ideas are implemented after individuals are urged to accept the changes. In this stage, reinvention will be done whereby the innovations will be modified as per the understanding of the employees. The last stage will be confirmation of the implemented ideas. The organization can now seek support from other stakeholders so as to bring the innovations into practice (Rogers, 2003). 
Innovation diffusion theory is one of the most relevant theories in determining the use of innovation strategy in the organization (Camisón, 2013; Nadkarni, \& Herrmann, 2010). As many scholars and researchers across the globe have noted, innovation diffusion theory clearly puts across the need for organizations to invest in innovations (Carlo, Lyytinen \& Rose, 2012; Saraf, Liang, Xue, \& Hu, 2013). This therefore makes the theory essential in the study in supporting the third objective of the study of strategic innovation on the competitiveness of TVET institutions in Kenya.

\section{Conceptual Framework}

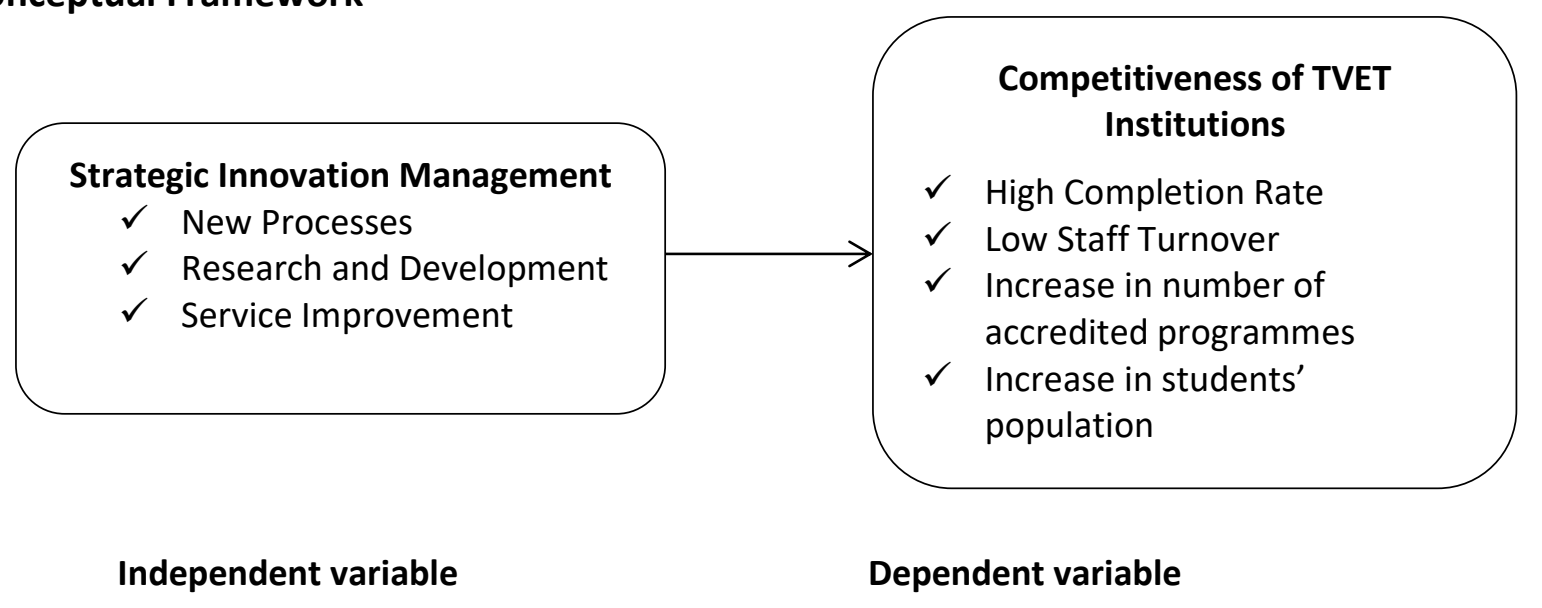

\section{Empirical Literature Review}

Hollanders and Evangelista (2012) using a feasible approach, conducted a study on promises and pitfalls of organisational and marketing innovation found that organisational and marketing innovations are deployed by a considerable share of European enterprises in order to gain economic success and competitive advantage. But due to the highly complex nature and strong reference to related fields of product innovation (in the case of marketing) and technical process innovation (in the case of organisational innovation), their economic effects are more likely to become visible as indirect effects in terms of enablers and prerequisites for innovation. Nevertheless, the findings show that organisational and marketing innovation can also contribute to firms' direct economic performance in terms of sales growth and increases in productivity. Based on the analysis of selected organisational concepts, the findings also depict that different organisational measures vary in their linkage to different economic performance dimensions (Hollanders \& Evangelista, 2012).

Wachira (2013) carried out an investigation on the impacts of advancement on monetary execution of business banks in Kenya. The scientist went for discovering the advancements that business banks had connected and put resources into to build their money related execution. The study adopted a cross sectional descriptive research design and had a sample population of 39 respondents from the all the commercial banks in Kenya. The study found that innovations enabled the commercial banks to enlarge and increase more customers. According to Kirugi and Mwebia (2016) as cited by Wachira (2013), commercial banks performed better when more innovative ideas were put in place and this saw many of them emerge to be the market leaders.

\section{Methodology}

\section{Research Design}

Descriptive research design was used in this study. It entails explanation of a phenomenon, estimating a proportion of a population with similar characteristics and ascertaining the 
relationship that occurs amid the variables under study (Myers, 2013; Saunders, Thornhill \& Lewis, 2009).

\section{Target Population and Sampling}

The accredited TVET institutions in Kenya were targeted. According to Ministry of Education (MOE-2018), there are 68 registered operational TVET institutions in Kenya. A census was used whereby all the 68 TVET institutions were selected while the principals, heads of finance department, heads of ICT and heads of R\&D were purposively selected making the ample size to total to 272 respondents. The respondents were surveyed using a structured questionnaire.

\section{Data Analysis}

Both descriptive and inferential statistics were used to analyze quantitative data while the qualitative data was analysed through description and thematic analysis. Descriptive statistics such as frequency distribution and measures of central tendency was used to analyse the demographic data. Testing of the hypothesis was done by calculating an F-Value using a twoway ANOVA.

\section{Findings}

\section{Strategic Innovation Management in TVET Institutions}

The study sought to establish the influence of strategic innovation on the competitiveness of TVET institutions in Kenya. The study focused on the three main aspects of strategic innovation which are service improvement, new processes and research and development. The findings are as shown in Table 1. The findings are in line with Cemoglu and Cao (2010) who indicated that process innovation is about improving the existing processes, bringing in new processes to improve efficiency and withdrawing processes that affect the efficiency and which that lead to wastage of organizational resources. The findings also compare with those by Moghli, Al Abdullah and Al Muala (2012) who found out that through enhanced process innovation, improving the existing processes and products as well as financing innovation create a better way of enhancing competitiveness and standing out from the competitors. 


\begin{tabular}{|l|l|l|l|l|l|l|l|}
\hline Statement & $\mathbf{D}$ & $\mathbf{D}$ & $\mathbf{N}$ & $\mathbf{A}$ & $\mathbf{S A}$ & $\begin{array}{l}\text { Mea } \\
\mathbf{n}\end{array}$ & $\begin{array}{l}\text { Std. } \\
\text { Dev. }\end{array}$ \\
\hline $\begin{array}{l}\text { The reporting and admission procedures } \\
\text { have been improved in the institution }\end{array}$ & $.7 \%$ & $10.9 \%$ & $25.3 \%$ & $42.8 \%$ & $15.3 \% 3.51$ & 1.06 \\
\hline $\begin{array}{l}\text { There is frequent review of operational } \\
\text { processes to enhance efficiency }\end{array}$ & $0.5 \%$ & $19.7 \%$ & $14.4 \%$ & $29.7 \%$ & $25.8 \% 3.61$ & 1.04 \\
\hline $\begin{array}{l}\text { Any processes leading to waste of time } \\
\text { and resources have been dropped }\end{array}$ & $.4 \%$ & $10.5 \%$ & $11.4 \%$ & $35.8 \%$ & $34.9 \% 3.80$ & 1.23 \\
\hline $\begin{array}{l}\text { Processes that are more compatible } \\
\text { with the institution have been adopted }\end{array}$ & $.7 \%$ & $8.7 \%$ & $13.1 \%$ & $48.9 \%$ & $27.5 \% 3.92$ & 0.95 \\
\hline $\begin{array}{l}\text { There is a budget set for research and } \\
\text { development in my institution }\end{array}$ & $.6 \%$ & $10.5 \%$ & $18.8 \%$ & $48.5 \%$ & $19.7 \% 3.72$ & 0.98 \\
\hline $\begin{array}{l}\text { Research is upheld in the institution to } \\
\text { provide a platform for innovation }\end{array}$ & $.9 \%$ & $9.6 \%$ & $11.8 \%$ & $42.4 \%$ & $32.3 \% 3.90$ & 1.08 \\
\hline $\begin{array}{l}\text { Through research new courses, systems } \\
\text { and/or procedures have been identified } \\
\text { in the recent past }\end{array}$ & $.1 \%$ & $7.4 \%$ & $16.6 \%$ & $40.2 \%$ & $29.7 \% 3.80$ & 1.13 \\
\hline $\begin{array}{l}\text { Top management provides an enabling } \\
\text { environment for trainers and trainees to } \\
\text { come up with own innovations }\end{array}$ & $6.4 \%$ & $17.5 \%$ & $24.9 \%$ & $7.2 \%$ & $14.0 \% 3.12$ & 1.14 \\
\hline $\begin{array}{l}\text { The Management adequately finances } \\
\text { students to execute innovations }\end{array}$ & $.1 \%$ & $9.2 \%$ & $23.6 \%$ & $31.4 \%$ & $29.7 \% 3.69$ & 1.17 \\
\hline $\begin{array}{l}\text { Trainees are advised on patenting their } \\
\text { innovations }\end{array}$ & $.4 \%$ & $9.2 \%$ & $21.4 \%$ & $44.1 \%$ & $21.0 \% 3.68$ & 1.04 \\
\hline $\begin{array}{l}\text { The service delivery in the institutions } \\
\text { have been improved as a result of } \\
\text { innovation }\end{array}$ & $.9 \%$ & $10.9 \%$ & $17.5 \%$ & $45.4 \%$ & $18.3 \% 3.55$ & 1.14 \\
\hline $\begin{array}{l}\text { The institution is committed to enhance } \\
\text { efficiency through coming up with new } \\
\text { ways of doing things and procedures }\end{array}$ & $.2 \%$ & $8.7 \%$ & $20.1 \%$ & $34.9 \%$ & $31.0 \% 3.78$ & 1.13 \\
\hline $\begin{array}{l}\text { Departments in the institution are } \\
\text { networked for ease of communication }\end{array}$ & $.0 \%$ & $7.0 \%$ & $16.6 \%$ & $45.0 \%$ & $24.5 \% 3.73$ & 1.12 \\
\hline $\begin{array}{l}\text { Satisfaction among the students has } \\
\text { been enhanced due to improved service } \\
\text { deliver }\end{array}$ & $1.6 \%$ & $19.2 \%$ & $11.8 \%$ & $43.7 \%$ & $15.7 \% 3.37$ & 1.23 \\
\hline
\end{tabular}

Table 1: Descriptive Results on Strategic Innovation

\section{Competitiveness of the TVET Institutions in Kenya}

The study sought to establish the competitiveness of TVET institutions in Kenya and the major aspects of competitiveness used included the number of accredited courses, staff turnover, rates of completion and intake. The findings as shown in Figure 2 revealed that in the year 2014 , the average number of accredited courses in the institutions was 19 which increased to 21 in the year 2015 and to 26 and 29 in 2016 and 2017 respectively. The findings further revealed that the average number of staff in the institutions was unstable over the years under the study. In the year 2014, the institutions had an average of 169 members of staff and this number increased to 253 in the year 2015 and to 261 in the year 2016. The findings 
imply that the institutions had newer courses over the years although the increase was very minimal. According to Kyaw and Naing (2015), TVET colleges ought to come up with newer courses as frequently as possible as a show of enhanced innovation but they should not duplicate courses.

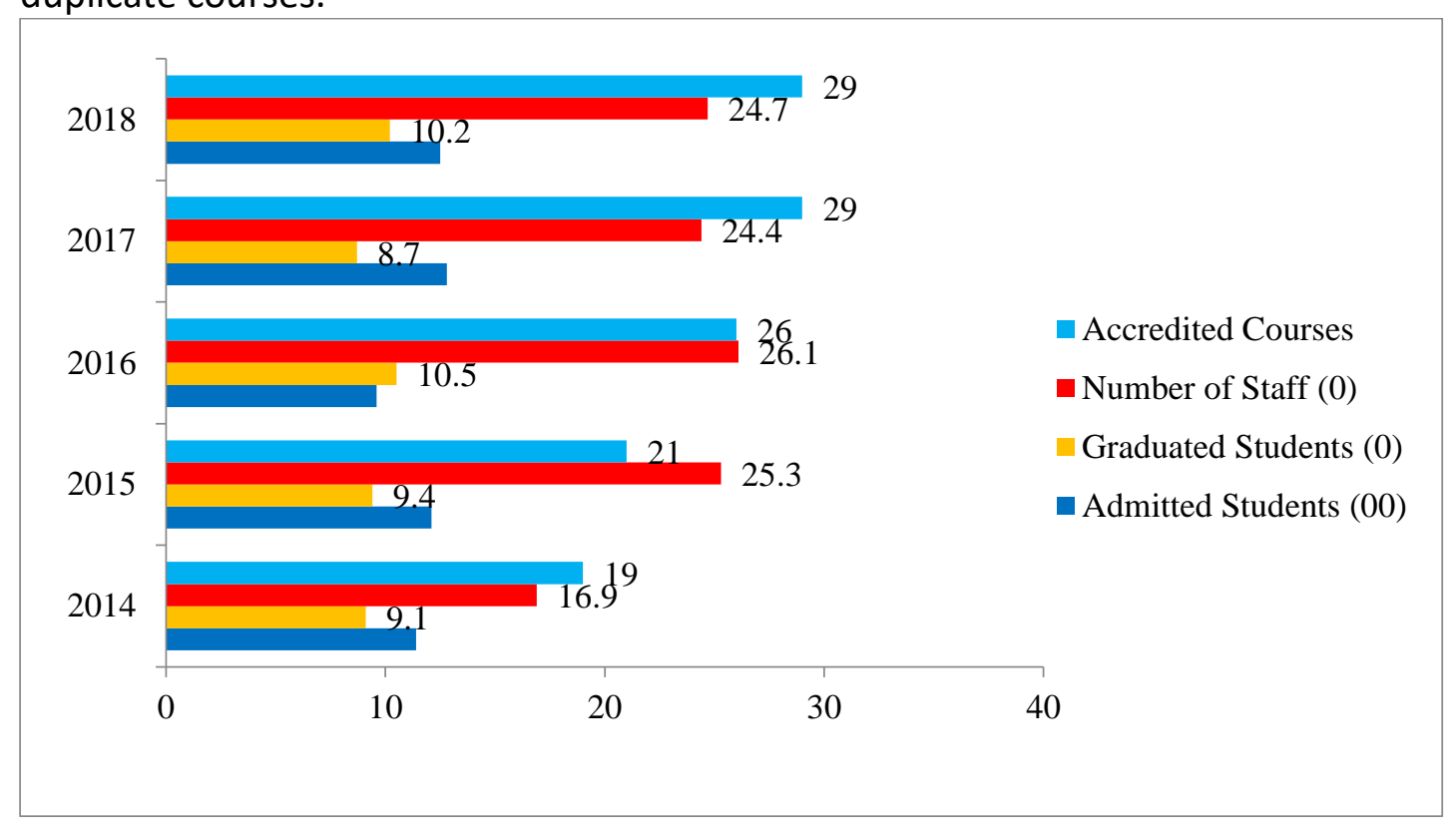

Figure 2: Competitiveness of TVET Institutions

\section{Hypothesis Testing}

The research hypothesis was that strategic innovation has no significant influence on the competitiveness of TVET institutions in Kenya. The linear regression model was adopted and model summary, ANOVA test and regression coefficients were the main outputs. As the model summary results in Table 2 reveal, the $R^{2}$ for the model was 0.350 . This implies that up to $35 \%$ of the variations in competitiveness of the TVET institutions can be explained by strategic innovation. The ANOVA test results revealed that the F-static for the model was 122.135 at a significance level of 0.000 . This implies that the model could statistically significantly predict the relationship between strategic innovation and competitiveness of TVET institutions in Kenya.

The regression coefficients results indicate, the Beta $(\beta)$ coefficient for the variable was 0.526 at a $\mathrm{P}$-value of 0.000 . The proposed model $\mathrm{Y}=\boldsymbol{\alpha}+\boldsymbol{\beta}_{1} \mathbf{X}_{1}+\boldsymbol{e}$; now becomes $\mathrm{Y}=\mathbf{1 . 8 0 8 +}$ $\mathbf{0 . 5 2 6 X _ { 1 }}+\mathbf{0 . 0 4 8}$. The results imply that a unit change in strategic innovation could lead up to $52.6 \%$ increase in the competitiveness of TVET institutions in Kenya. This leads to the decision to reject the null hypothesis that strategic innovation has no significant influence on the competitiveness of TVET institutions in Kenya. 
Table 2: Regression Model Results

Model Summary

\begin{tabular}{|l|l|l|l|l|}
\hline Model & $R$ & R Square & Adjusted R Square & $\begin{array}{l}\text { Std. Error of the } \\
\text { Estimate }\end{array}$ \\
\hline 1 & $.591^{\mathrm{a}}$ & .350 & .347 & .85898 \\
\hline \multicolumn{2}{|l}{ a. Predictors: (Constant), Strategic Innovation }
\end{tabular}

ANOVA

\begin{tabular}{|l|l|l|l|l|l|l|}
\hline \multicolumn{2}{|l|}{ Model } & $\begin{array}{l}\text { Sum of } \\
\text { Squares }\end{array}$ & df & $\begin{array}{l}\text { Mean } \\
\text { Square }\end{array}$ & F & Sig. \\
\hline \multirow{2}{*}{1} & Regression & 90.117 & 1 & 90.117 & 122.135 & $.000^{\mathrm{b}}$ \\
\cline { 2 - 7 } & Residual & 167.492 & 227 & .738 & & \\
\cline { 2 - 7 } & Total & 257.609 & 228 & & & \\
\hline
\end{tabular}

Regression Coefficients

\begin{tabular}{|l|l|l|l|l|l|l|}
\hline \multicolumn{2}{|l|}{ Model } & \multicolumn{2}{l|}{$\begin{array}{l}\text { Unstandardized } \\
\text { Coefficients }\end{array}$} & $\begin{array}{l}\text { Standardized } \\
\text { Coefficients }\end{array}$ & t & Sig. \\
\cline { 3 - 7 } \multicolumn{2}{|l|}{} & B & Std. Error & Beta & & \\
\hline \multirow{2}{*}{1} & (Constant) & 1.808 & .192 & & 9.413 & .000 \\
\cline { 2 - 6 } & $\begin{array}{l}\text { Strategic } \\
\text { Innovation }\end{array}$ & .526 & .048 & .591 & 11.051 & .000 \\
\hline
\end{tabular}

a. Dependent Variable: Competitiveness

The findings revealed that majority of the respondents agreed that their respective institutions had improved the procedures for reporting and admission and that there were frequent reviews of the operations process of the institutions to enhance efficiency. The institutes were dropping down any process that is costly and time-consuming while they adopted the processes that were more compatible with their goals and objectives. Most of the institutions surveyed had a budget for research and development (R\&D) and they upheld research as an avenue for enhancing innovation. The respondents stated that through enhanced innovation in their respective institutions, the service delivery was increased and this improved the students' satisfaction. The regression analysis model revealed that there was a significant and positive relationship between strategic innovation and competitiveness of the TVET institutions in Kenya, The model output further revealed that there was a significant moderating effect of institutional culture on the relationship between strategic innovation and competitiveness of TVET institutions in Kenya.

\section{Conclusions and Recommendations}

The study concluded that strategic innovation management was a key aspect in enhancing the competitiveness of TVET institutions in Kenya. As a strategic leader, innovation is one of the major approaches to enhance the effectiveness and efficiency of service delivery. The TVET institutions recognized the role of strategic innovation but this was not effectively upheld hence it did not enable them achieve the full potential through new processes, enhanced research and development and improvement of the services. 
The management of the TVET institutions has the main duty of ensuring that the process and procedures adopted in their institutions are in line with the changing operating environment. This can be ensured through proper uptake and support of innovation by doing adequate research to come up with new processes and ensure abolishing of processes that are costly and time consuming. The management should be at the forefront of embracing service improvement and uniqueness in operation as well as supporting innovation among the employees.

The study revealed that strategic innovation is a key enabler to the competitiveness of TVET institutions in Kenya. The study therefore contributes to the existing knowledge that TVET in institutions can be innovative by introducing new processes and enhancing service improvement through research and development in order to steer their competitiveness. The study also contributes to the existing theory by revealing the diffusion innovation theory explains the application of innovation management in TVET institutions. This brings a more dynamic viewpoint of the diffusion innovation theory in regard to competitiveness of TVET institutions in Kenya.

\section{References}

Ali, M., \& Hadi, A. (2012). Surveying and identifying the factors affecting successful implementation of business strategies in companies of Fars province industrial towns (case study: companies of food industries). International Journal of Business and Social Science, 3, 265-272.

Al-Shboul, M., Delage, T., \& Germain, K. (2017). Which Survey Questions Change Behavior? Randomized Controlled Trial of Mere Measurement Interventions. American Psychological Association, 26(6), 636-644.

Anderson, P. (2014). Mergers and Acquisitions: An Empirical Study on the Post-Merger Performance of Selected Corporate Firms in India. IUP Journal of Business Strategy, 10(4), 7-67.

Anwar, J., \& Hasnu, S. A. F. (2017). Ideology, Purpose, Core Values and Leadership: How they influence the Vision of an Organization? International Journal of Learning and Development, 3(3), 168-184.

Arham, A. F. (2014). "Leadership and Performance: The Case of Malaysian SMEs in the Services Sector." International Journal of Asian Social Science, 4(3), pp. 343-355.

Armstrong, M. (2013). Armstrong's Handbook of Human Resource Management practice. (12th Ed.). UK. Ashford Colour Press.

Cronbach, L. J. (1951). Coefficient alpha and the internal structure of tests. Psychometrika, Vol. 22(3), pp. 297-334.

Cronbach, L. J. (1984). A research worker's treasure chest. Multivariate behavioral research, 19(2-3), 223-240.

Damodar, P. J. (2010). Defining the 'positive' in positive psychology: Part I. A descriptive analysis. The Journal of Positive Psychology, 11(4), 339-356.

Dimitrios, N. K., Sakas, D. P., \& Vlachos, D. S.- (2013). Analysis of strategic leadership models in information technology. Procedia Soc Behav Sci, 73, 268-275.

Dimitrios, N. K., Sakas, D. P., \& Vlachos, D. S. (2013). Investigation of key authority recreation models in non-benefit associations. Social and Behavioral Sciences, 73, $276-284$.

Dyllick, T., \& Muff, K. (2016). Article; Clarifying the Meaning of Sustainable Business: Introducing a Typology from Business-as-Usual to True Business Sustainability. 
Fraenkel, J. R., \& Wallen, N. E. (2003). How to design and evaluate research in education. Fifth ed. New York: McGraw-Hill.

Kising'u, T. M., Namusonge, G. S., \& Mwirigi, F. M. (2016). The role of organizational learning in sustainable competitive advantage in universities in Kenya. Account and Financial Management Journal, 1(5), 335-359.

Kitonga, D. M. (2017). Strategic leadership practices and organizational performance in notfor-profit organizations in Nairobi County in Kenya. PhD thesis, Juja: JKUAT).

Kitonga, D. M., Bichanga, W. O., \& Muema, B. K. (2016a). Strategic leadership and organizational performance in not-for-profit organizations in Nairobi County in Kenya. International Journal of Scientific and Technology Research, 5(5), 17-27.

McCleskey, J. A. (2014). Situational, Transformational, and Transactional Leadership and Leadership Development. Journal of Business Studies Quarterly, 5(4), 117.

Nthini, E. K. (2013). Effect of Strategic Leadership on the Performance of Commercial and Financial State Corporation in Kenya. School of Business University of Nairobi.

Cetin, M., Karabay, M. E., \& Efe, M. N. (2012). The Effects of Leadership Styles and the Communication Competency of Bank Managers on the Employee's Job Satisfaction: The Case of Turkish Banks. Procedia Social Behavioral Science 58227

Parsons, A., \& Urdapilleta, E. (2016). Expanding Bank Outreach through Retail partnerships: Correspondent Banking in Brazil World Bank Working Paper No. 85. The World Bank: Washington DC.

Paul, K. (2012). The role of external knowledge in open innovation- A systematic Review of literature. Proceedings of the European Conference on Knowledge Management, p592.

Pearce, J. A., \& Robinson, R. B. (2011). Strategic Management: Formulation, Implementation, and Control. New York: Mc Graw Hill/Irwin.

Prahalad, C. K., \& Ramaswamy, V. (2009). Co-creating unique value with customers. Strategy \& leadership, 32(3), 4-9.

Pulic, A. (2012). Intellectual capital - does it create or destroy value? Measuring Business, 6(7), 32-45.

Ringim, K. J., Osman, N. H., Hasnan, N., \& Razalli, M. R. (2013) Exploring the implementation of business process reengineering in banks. Asian Social Science 9, 243

Schultz, W. (1961). Investment in Human Capital. The American Economic Review, Volume II No.1.

Sekaran, U., \& Bougie, R. J. (2016). Research methods for business: A skill building approach. Chichester, West Sussex: John Wiley \& Sons.

Strickland, J. (2012).Crafting and Implementing Strategy, Texts and Readings, 10thEdition, McGraw Hill, New York.

Technical, Vocational, Education and Training Authority. (2017). TVET Institutions in Kenya.

Technical Vocational Education and Training Authority - TVETA. (2018). Strategic plan 20182022. Government Printer, Kenya.

TEN/MET. (2017).Strengthening Education in Tanzania; Contribution to the Education sector Kenya.

UNESCO. (2016).Literacy for life; EFA Global Monitoring Report. Nairobi; Government Printer Vanhaverbeke, W., Duysters, G., \& Van den Oord, A. (2016). Network embeddedness strategic Leadership: Technological distance, betweenness centrality and density. Research Policy, 37, 1717-1731. 
Vonta, F. (2008). Statistical models and methods for biomedical and technical systems. Boston, Mass: Birkhäuser.

Wijetunga, W. A. S. (2013). 'The relationship between strategic planning and business performance: An empirical study of manufacturing SMEs in western province in Sri Lanka', master's thesis, University of Sri Jayewardenepura, Sri Jayewardenepura, Sri Lanka.

World Bank. (2013). Economic Growth and Public Policy, New York: Oxford University Press.

Yaseen, S. (2014). 'Mobile Crowdsourcing Technology Acceptance and Use in the Crises Management of Arab Spring Societies', 10th International Academic Conference, Vienna.

Yeok M. H. K., Basit, A., \& Zubair, H. (2018). The Impact of Strategic Leadership on Organizational Performance of Small Medium Enterprises (SME) in Malaysia. Journal of Leadership and Management, 13 (18) 154-166.

Zain, Z. M. (2011). TVET in Malaysia. Retrieved, from http://dspace.unimap.edu.my/dspace/bitstream/123456789/7186/1/TVET\%20in\%2 OMalaysia.pdf

Zikmund, K. (2010). Insiders, outsiders and participatory evaluation. In J.C. Alderson \& A. Beretta (Eds.), Evaluating second language education (pp. 25-60). Cambridge: CUP. 